\title{
THE WEATHER AND CIRCULATION OF MAY 1951
}

LeROY H. CLEM

Extended Forecast Section, U. S. Weather Bureau, Washington, D. C.

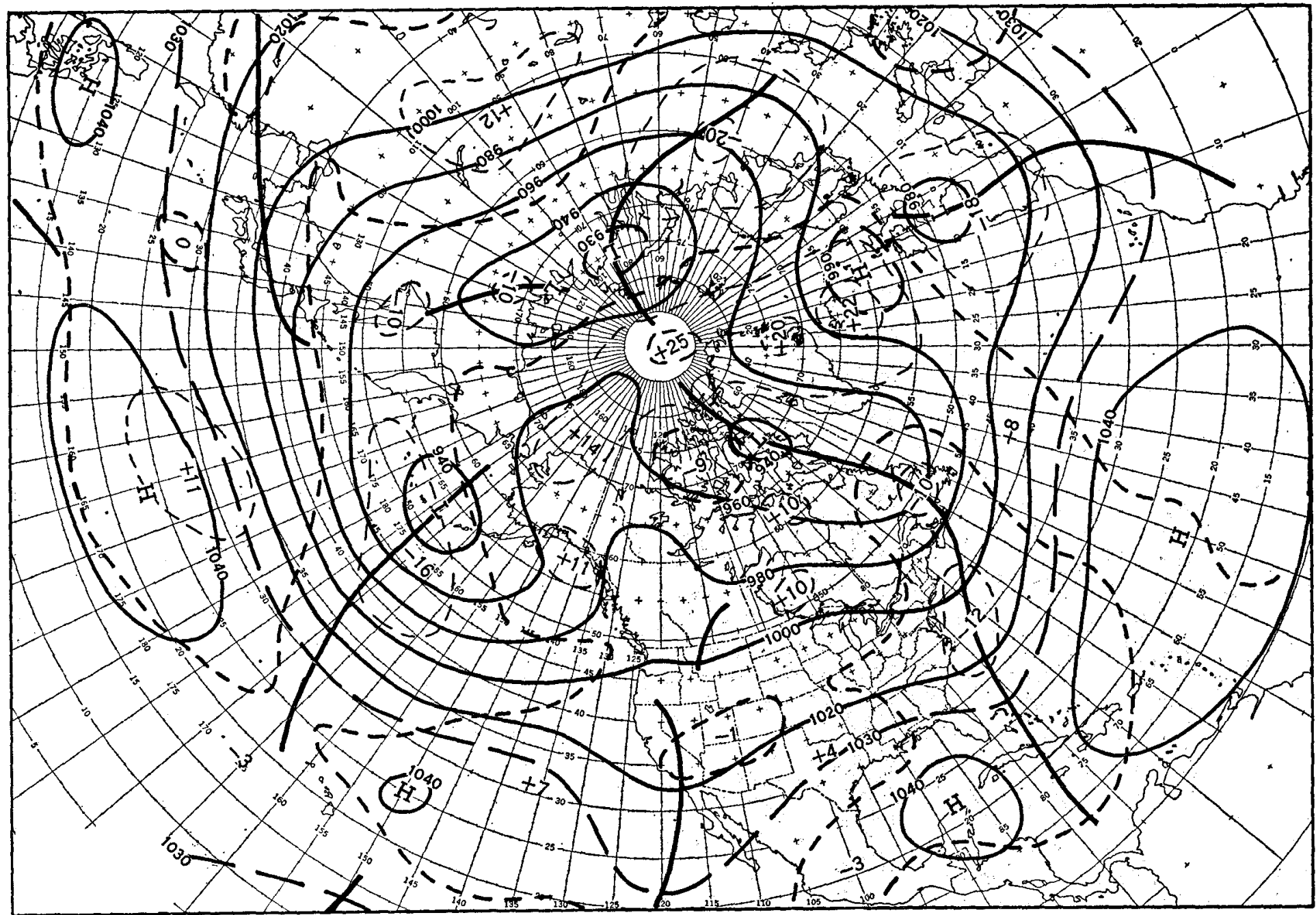

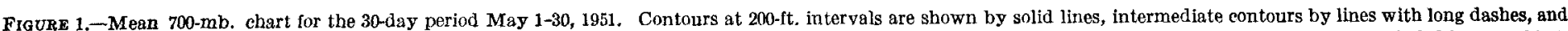


Minimum latitude trough locations are shown by heavy solid lines.

\section{THE CIRCULATION}

An important feature of the mean circulation over North America and the adjacent oceans in May 1951 was the trough off the east coast of the United States at both sea level and aloft (fig. 1 and Charts XI-XV). ${ }^{1} \quad 700-\mathrm{mb}$. heights were below normal in this trough at middle and low latitudes (fig. 1), while sea level pressures were below normal throughout the extent of the trough from the Bahamas to Baffin Bay (Chart XI inset). On the monthly

I See Charts. I-XV following page 105 for analyzed climatological data for the month. mean 700-mb. chart two distinct centers of negative $700-\mathrm{mb}$. height anomaly appear in the trough (fig. 1). One center, over the Gulf of St. Lawrence, was the seat of cyclonic activity during the first half of the month, while the other center, off the Carolinas, was prominent during the last 15 days of the month. Likewise, the ridge upstream was characterized by two separate centers of positive 700-mb. height anomaly, one north of Minnesota and the other over Texas. The trough in the southwestern United States was approximately normal in both intensity and position. In the Pacific a deep single-celled Aleutian 
Low was south of the normal position while a strong blocking type ridge dominated Alaska and the Arctic. Blocking was even more pronounced in the eastern Atlantic where a closed warm High was longitudinally superimposed upon a cold cut off Low. As a result below normal heights persisted for the eleventh consecutive month over part of the British Isles [1] [2].

Further information about the mean circulation for May can be obtained from the field of mean 700-mb. geostrophic wind speed (fig. 2). Some of the characteristics of the low index state which prevailed during April [2] and persisted during the first part of May are apparent in the mean wind field. Note the split in the mean monthly jet stream over the United States with one branch going north of the border and the other south of $35^{\circ} \mathrm{N}$. Neither of these two jets was particularly strong and between them the monthly wind speeds were quite weak with a minimum speed center located in Nevada. The westerlies also split as they approached the region of blocking in the eastern Atlantic. A center of maximum wind speed was located in the western Atlantic about 700 miles east of the trough off the East Coast. Such an eastward displacement of the wind maximum relative to the trough is generally found in a trough like this one with a pronounced northeast-southwest tilt. The maximum wind speeds $(17 \mathrm{~m}$. p. s.) shown in figure 2 were observed in the approximately straight flow between the Aleutian Low and the Pacific High cells. This jet nearly coincides with the zero line on the relative vorticity chart (fig. 3) since in cases of straight flow the relative vorticity pattern is determined by the wind shear.

The effect of the split jet over the North American region on the paths of cyclones is evident in Chart $\mathrm{X}$. Eastward moving cyclones either crossed Canada along the northern jet or traversed the United States north of the southern jet. However, the most intense and frequent storminess occurred in the regions of low pressure at sea level (Chart XI) and well-pronounced cyclonic vorticity aloft (fig. 3) associated with the troughs along the East Coast, in the mid-Pacific and in western North America. There was also a tendency for the cyclones to move along the major axis of the cyclonic vorticity field at $700 \mathrm{mb}$. In fact, several cyclones seemed to follow the vorticity channels more closely than they did the monthly mean contours.

Perhaps the most pronounced cyclonic activity was associated with the East Coast trough. As the lower latitude portion of this trough intensified after the middle of the month two tropical cyclones developed in the trough. One of these became a hurricane which first travelled southward off the Florida coast and then stalled over the Bahamas before it moved northward toward the Carolina Capes. A hurricane is quite a rarity in May in the subtropical Atlantic and this one was the earliest on record.

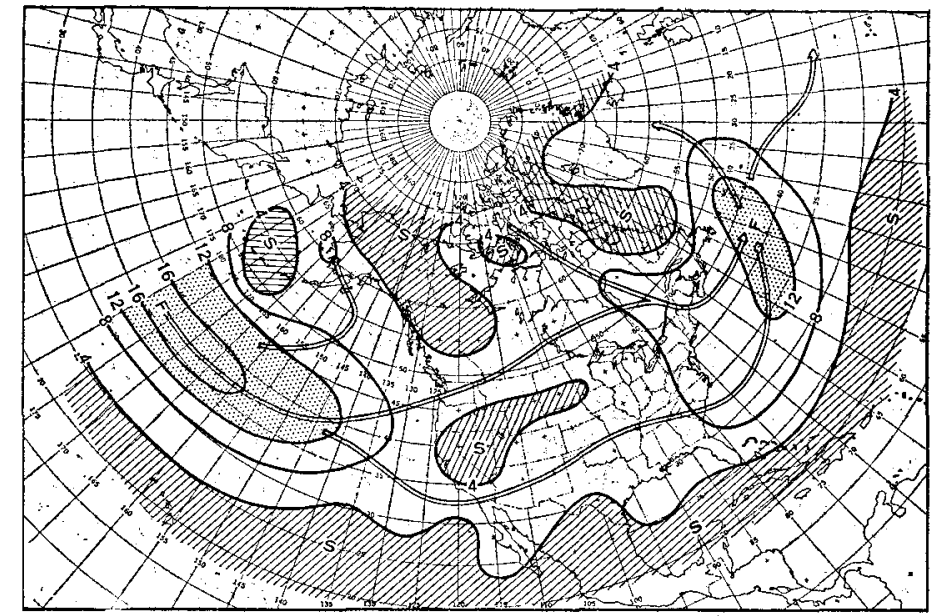

Fiove 2.- Mern geostrophic (total horizontal) wind speed at $700 \mathrm{mb}$. for the 30 -day period May 1-30, 1951. Solid lines are isotachs at intervals of $4 \mathrm{~m}$./sec. while the double arrowed lines delineate the axes of maximum wind speeds (jets). Areas with speeds in excess of $12 \mathrm{~m}$./sec. are dotted while those less than $4 \mathrm{~m} . / \mathrm{sec}$. are hatched. Centers of maximum and minimum wind speed are labeled " $F$ " and " $\mathrm{S}$ ", respectively.

Anticyclones during May (Chart IX) clustered and often intensified in the regions of anticyclonic vorticity at $700 \mathrm{mb}$. (fig. 3). There were exceptions however to the tendency for the movement of anticyclones to follow the axis of anticyclonic vorticity at $700 \mathrm{mb}$. Some Highs moved directly across regions of cyclonic vorticity but these were mostly shallow cold anticyclones [3] which generally weakened as they passed through these areas. It is interesting to note that no cyclones took the normal path up the St. Lawrence River Valley. This is not surprising, however, since this region was dominated by abnormally strong anticyclonic vorticity at $700 \mathrm{mb}$. (figs. 3 and 4).

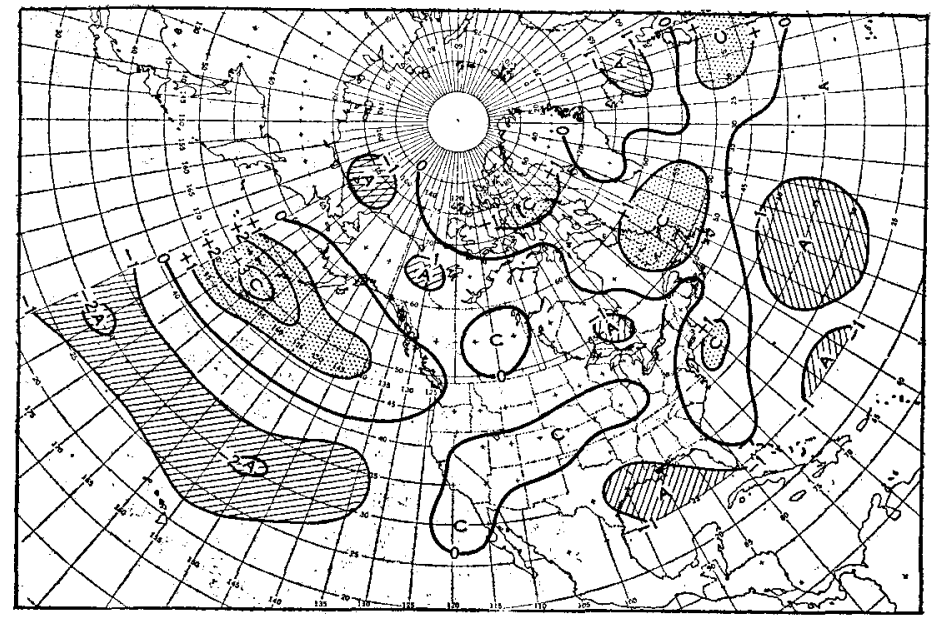

Figvre 3.-Vertical component of mean relative geostrophic vorticity at $700 \mathrm{mb}$. for the 30 -day period May 1-30, 1951, in units of $10^{-8} \mathrm{sec}-1$. Areas of cyclonic vorticity in excess of $1 \times 10^{-5}$ sec.-1 are dotted and labeled " $\mathrm{C}$ " at the center; areas of anticyclonic vorticity less than $-1 \times 10^{-5}$ sec.-1 are hatched and laboled " $A$ " at the center. 


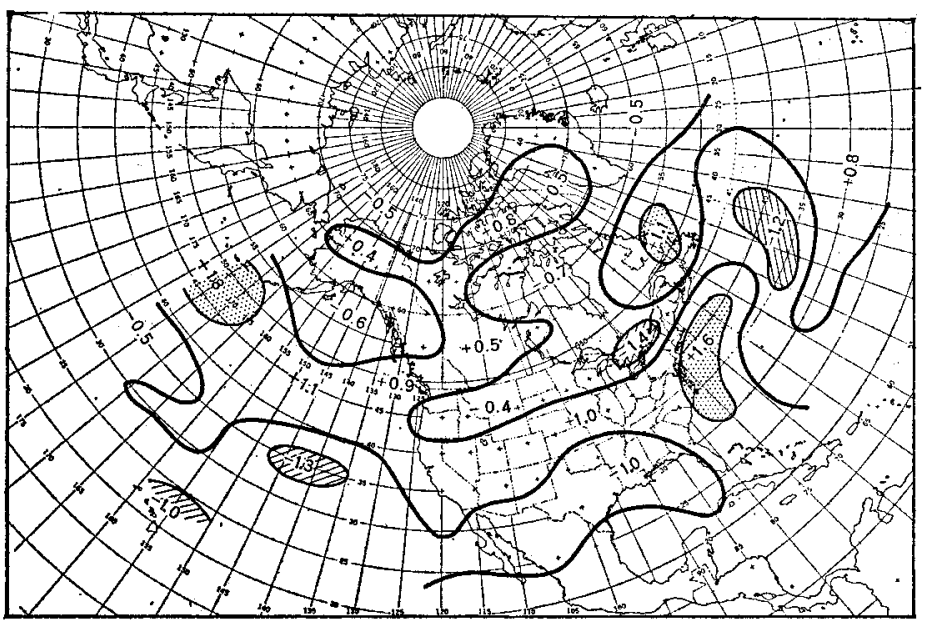

Figure 4.-Departure from normal of the vertical component of the mean relative geostrophic vorticity at $700 \mathrm{mb}$. for the 30 -day period May 1-30, 1951. Isopleths of departure from normal drawn at intervals of $1 \times 10^{-5}$ sec.-1 are shown by solid lines with the zero isopleths beavier than the others. Anomaly centers are labeled in units of $10^{-5}$ sec. -1 .

\section{THE WEATHER}

The pattern of the departure of average temperature from normal (Chart I inset) for May was quite a reversal from that of April [2]. Temperatures were above normal over most of the country with the largest anomaly (about $5^{\circ} \mathrm{F}$.) in parts of Wisconsin and Minnesota. The warm weather in the central United States was associated with above-normal heights and anticyclonic curvature at 700 mb. (fig. 1). In the Southwest, the $700-\mathrm{mb}$. flow relative to normal had a southerly component, while on the West Coast there was weak continental drift relative to normal at sea level (Chart XI inset). The percentage of sky cover (Chart VI A) was reduced in these areas, except the Northwest coast, and thus sunshine (Chart VII A) and solar radiation (Chart VIII) were abundant. The expected departure from normal of these elements is shown in Charts VI B, VII B, and VIII (inset).

Most of New England had above-normal temperatures in May. This was the eighth consecutive month of the prolonged warm regime there. Easterly drift relative to normal continued over this area at both sea level and aloft (Chart XI inset and fig. 1). In earlier months the warming effect of this oceanic drift on New England was quite obvious. However, in May, the sea surface temperatures here are normally cooler than adjacent land temperatures. There is some evidence that the cumulative effect of the onshore drift throughout the preceding warm months resulted in abnormally warm sea surface temperatures off the New England coast this year. Thus easterly drift relative to normal this month, contrary to the usual condition, actually kept New England warmer than normal.

Temperatures were below normal in the Middle and South Atlantic States as northerly flow to the rear of the trough at all levels transported more polar air than usual into this region. The weak trough along the northwest border was accompanied by slightly subnormal temperatures in Washington and Montana. The below-normal temperatures which stretched from North Texas to South Dakota were probably the result of heavy rain (Charts II, III $A$ and III B) and the accompanying cloudiness (Chart VI A) which reduced the sunshine (Chart VII A) and solar radiation (Chart VIII) to well below normal amounts (Charts VI B, VII B, and VIII inset).

Over most of the country May was a rather dry month (Chart III A and B). In fact, in several areas the shortage of rainfall was critical. The rainfall pattern, however, was broken up in typical summer fashion. Several areas of fairly heavy rain were associated with the trough in the Southwest. Parts of Northern California, Nevada, Oregon and Washington received more than normal amounts of rainfall early in the month. To the east of the trough in Arizona and Utah above-normal rainfall continued with amounts totalling more than 200 percent of normal. Unfortunately, very little precipitation reached New Mexico where serious drought conditions were experienced. Only later in the month was this relieved to some extent as shower activity began over the High Plains. The above-normal precipitation in Wyoming and Montana was connected with the weak trough in the Northwest and several storms which moved northward in the Rocky Mountain region (Chart IX).

The region of heaviest rainfall in the United States was centered in the Texas-Oklahoma Panhandles and southern Kansas where amounts exceeding 300 percent of normal were observed. Another region of heavy rainfall extended from North Platte to Chicago. The relatively dry zone between these centers reflects the discontinuous nature of frontal and shower type rainfall. Since only one cyclone passed through this area during the month, most of the rain in the Plains came from heavy showers and thunderstorms associated with several fronts and squall lines. Maritime tropical air, which was transported from the Gulf into the southern Plains at a more rapid rate than normal at sea level (Chart XI inset), supplied the moisture for this heavy rainfall. Some of this convective activity was associated with tornadoes which were more frequent than normal in Kansas and Oklahoma. The heavy rainfall in the Plains States caused many local floods. Serious conditions existed all along the upper Mississippi where levees had been softened by previous weeks of high water.

The small region of heavy rainfall on the mid-Gulf coast of Texas was the result of a cloudburst on the 7 th of May in the warm unstable Gulf air preceding a cold frontal passage. At Palacios the 24-hour rainfall amount was 9.26 inches which alone equals nearly 150 percent of the month's normal rainfall. However the rainfall was so concentrated that both the cloudiness and sunshine were about normal for the month (Charts VI B and VII B).

The above-normal precipitation along the East Coast was produced by coastal storms and the hurricane moving up the mean trough. This activity was reflected in the 
fields of relative vorticity at $700 \mathrm{mb}$. (fig. 3) and its departure from normal (fig. 4). Southeastern New England received much of its rain between the $23 \mathrm{~d}$ and 25th as a slow moving cold front stalled off the coast and a storm center developed on it. By the time this system had finally moved away, it had deposited amounts in excess of 3 inches of rain over the area.

The deep South experienced a serious drought condition that badly retarded the cotton planting. This was associated with stronger than normal ridge conditions at both sea level and $700 \mathrm{mb}$. (Chart XI and inset and fig. 1). Also related to these conditions was the presence of a center of departure from normal of anticyclonic vorticity over Louisiana (fig. 4). The only relief came late in the month with a few scattered showers. As might be ex- pected, this drought was accompanied by abnormally low percentages of sky cover (Chart VI), abnormally high percentages of possible sunshine (Chart VII) and excessive solar radiation (Chart VIII).

\section{REFERENCES}

1. W. H. Klein, "The Weather and Circulation of February 1951", Monthly Weather Review, vol. 79, No. 2, February 1951, pp. 35-38.

2. J. S. Winston, "The Weather and Circulation of April 1951", Monthly Weather Review, vol. 79, No. 4, April 1951, pp. 71-73.

3. J. A. Carr, "The East Coast 'Backdoor' cold front of May 16-20, 1951", Monthly Weather Review, vol. 79, No. 5, May 1951, pp. 100-105. 
Chart I. A. Average Temperature ( ${ }^{\circ}$ F.) at Surface, May 1951.

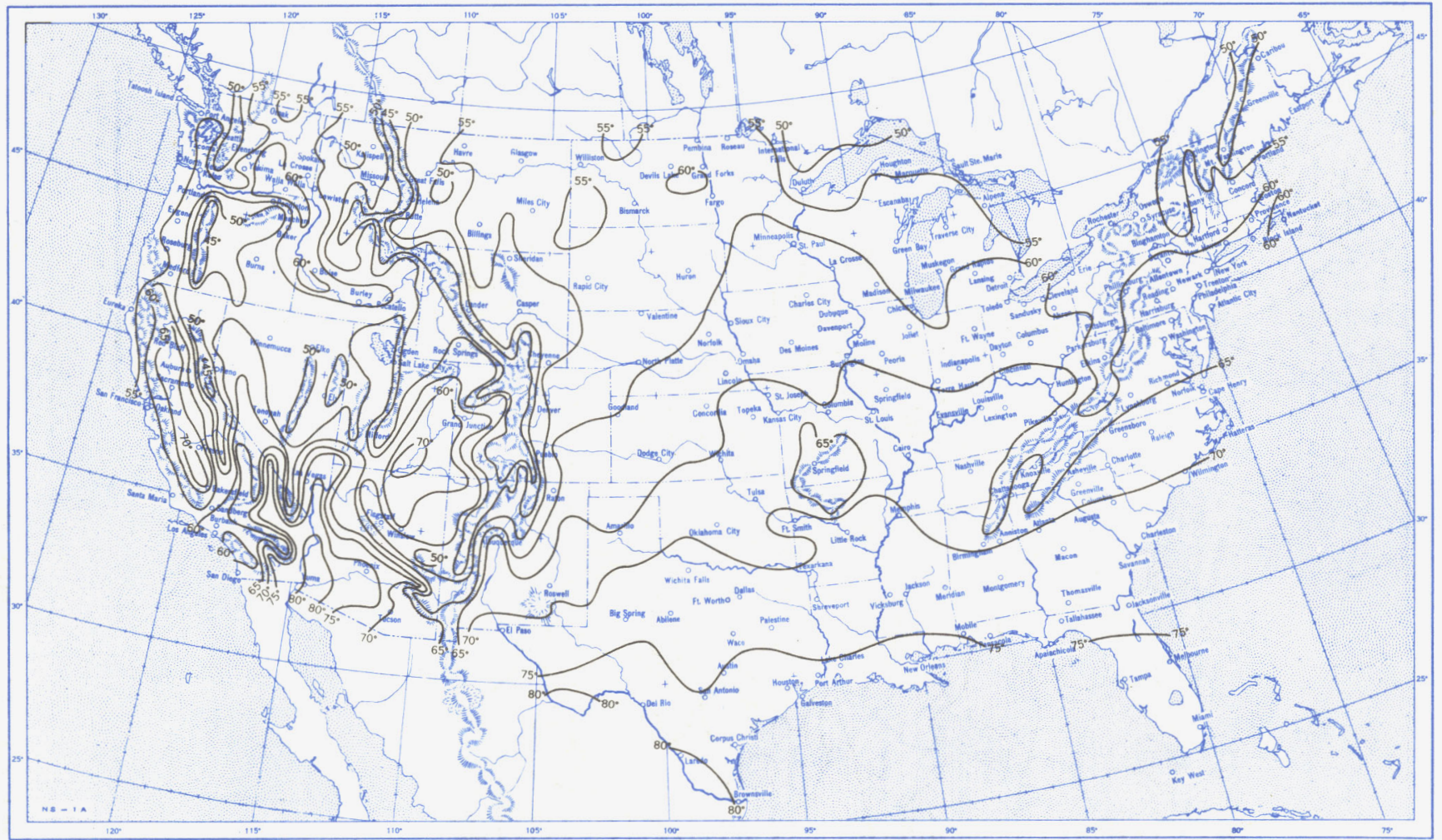

\section{B. Departure of Average Temperature from Normal ( $\left.{ }^{\circ} \mathrm{F}.\right)$, May 1951.}

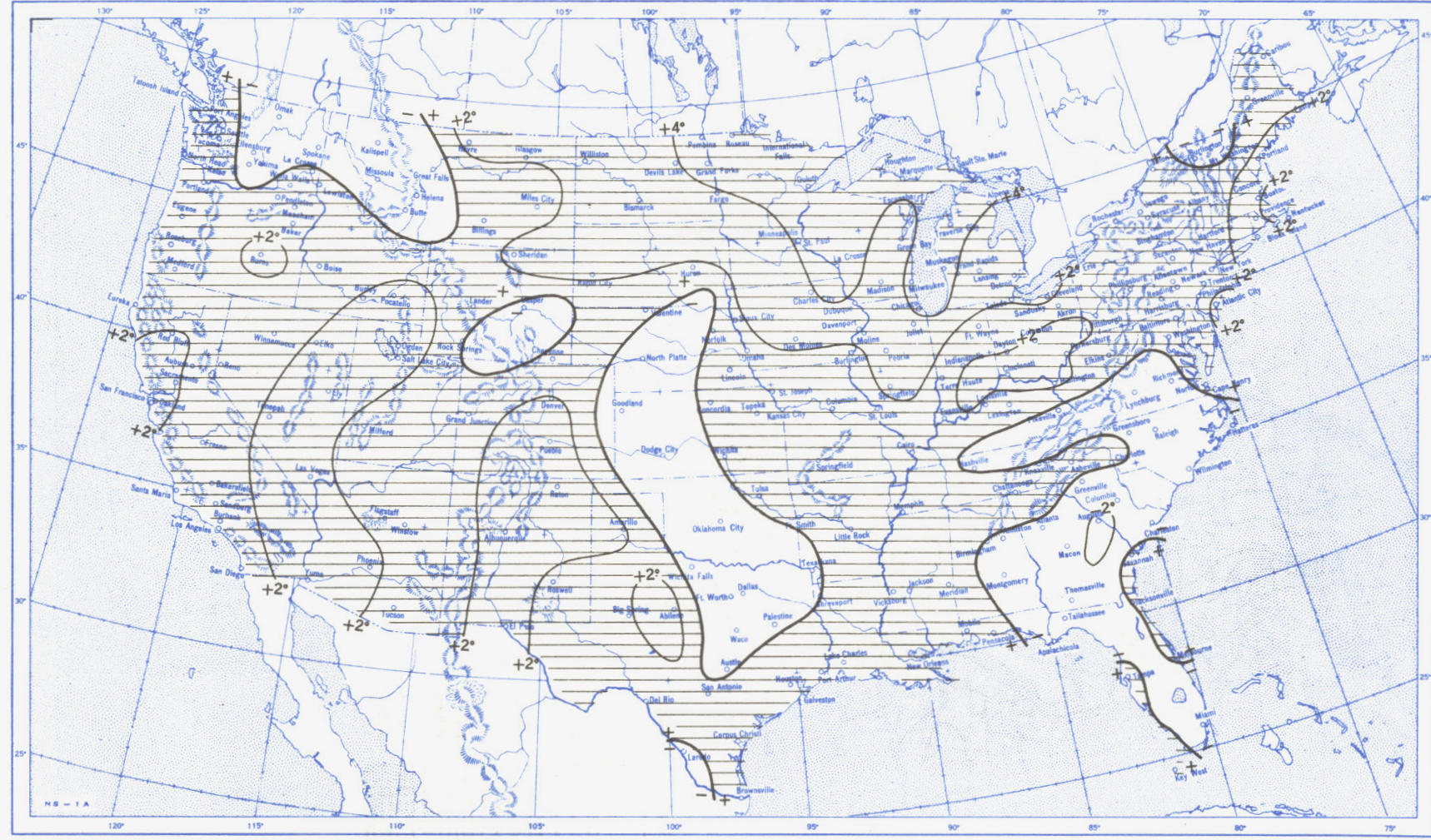

A. Based on reports from 800 Weather Bureau and cooperative stations. The monthly average is half the sum of the monthly average maximum and monthly average minimum, which are the average of the daily maxima and daily minima, respectively. B. Normal avierage monthly temperatures are computed for Weather Bureau stations having at least 10 years of record. 


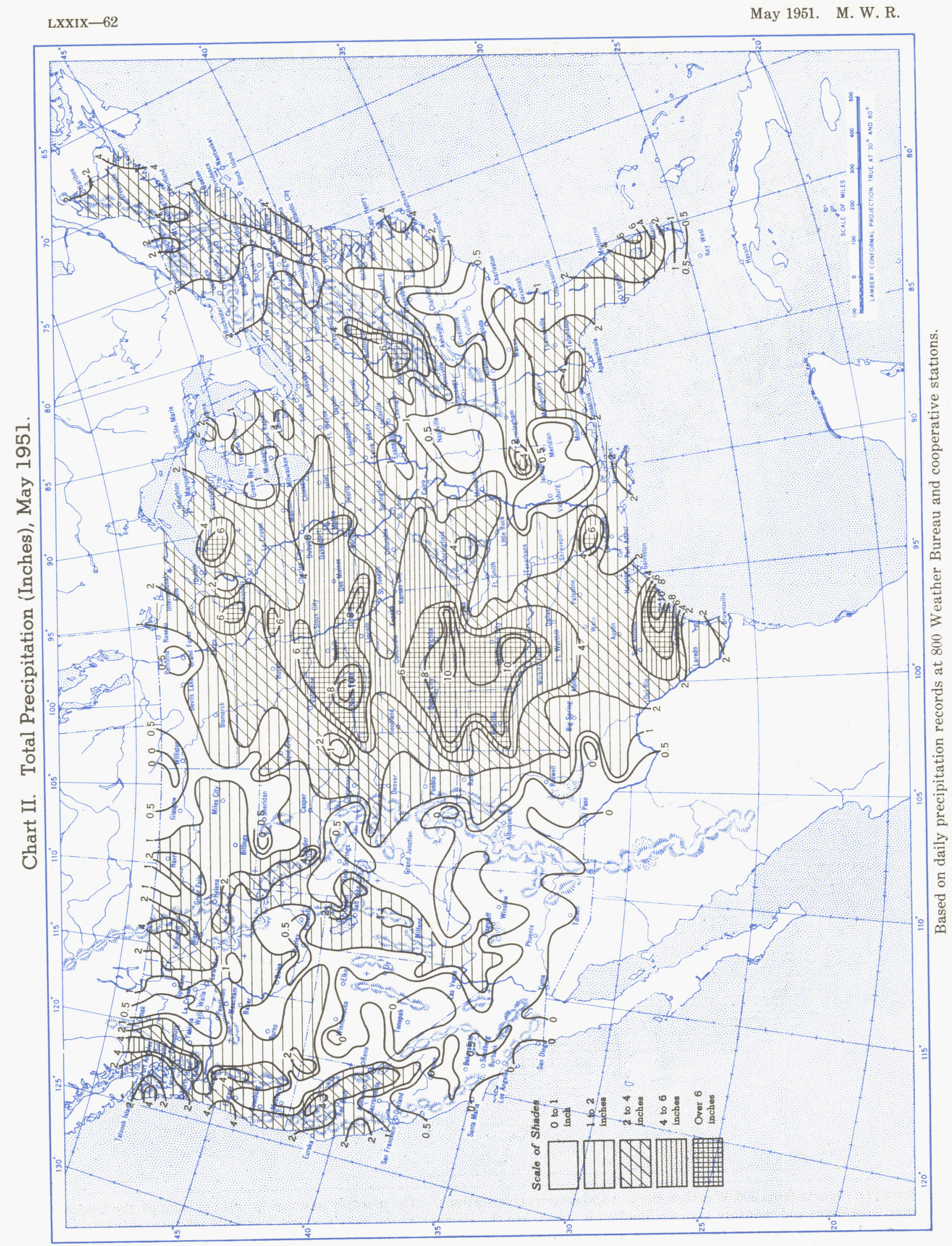


Chart III. A. Departure of Precipitation from Normal (Inches), May 1951.

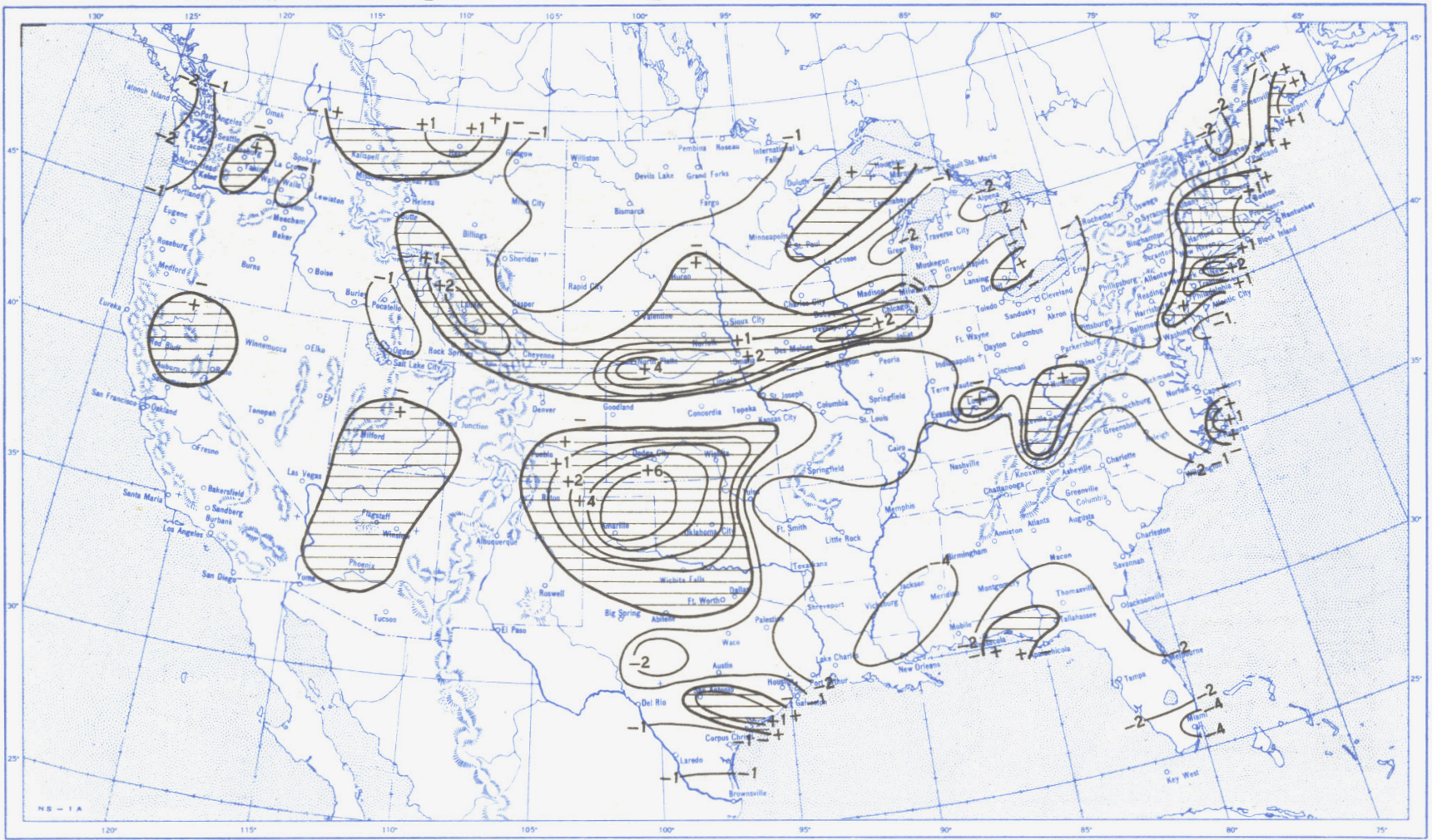

B. Percentage of Normal Precipitation, May 1951.

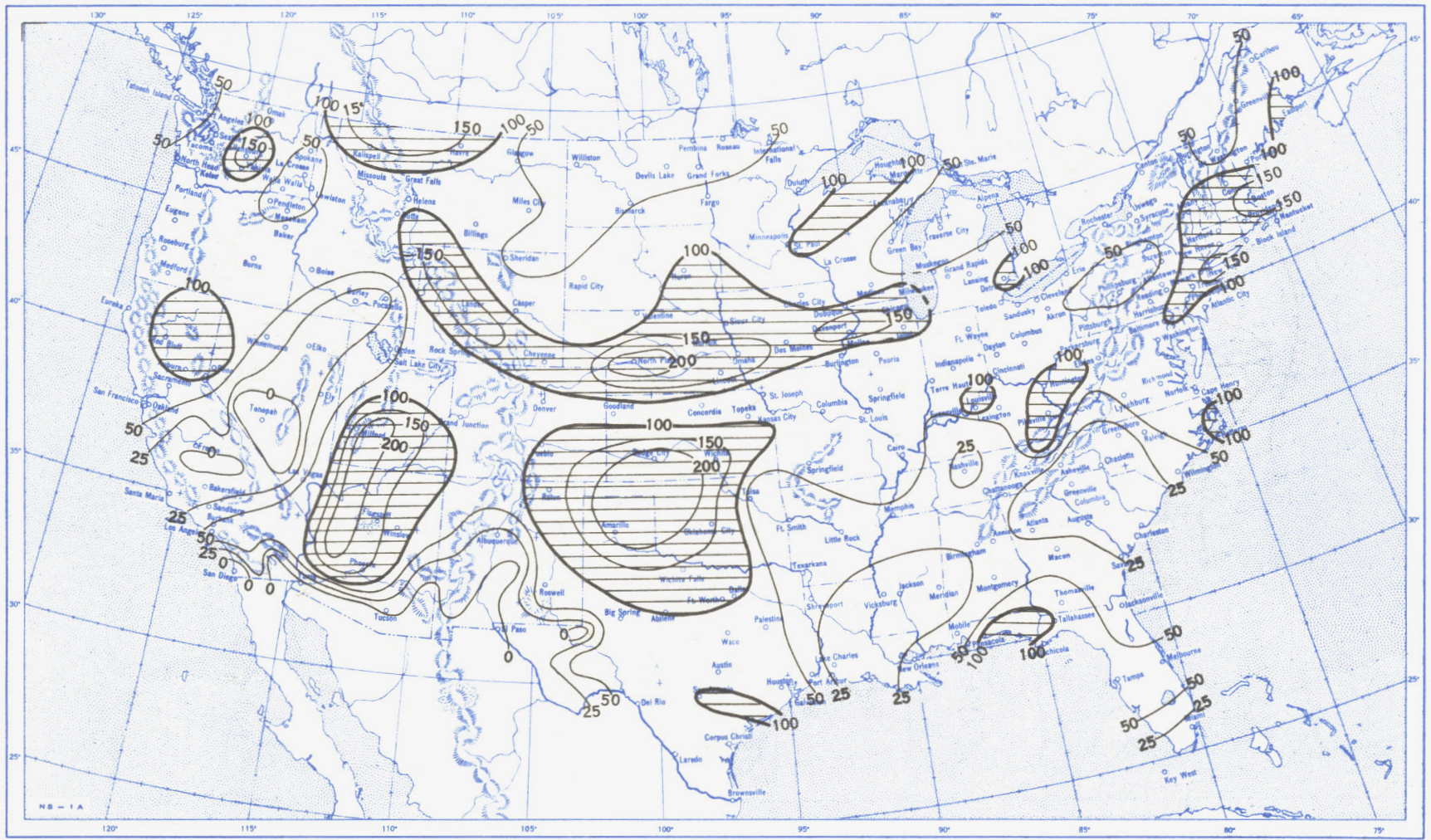

Normal monthly precipitation amounts are computed for stations having at least 10 years of record. 
Chart VI. A. Percentage of Sky Cover Between Sunrise and Sunset, May 1951.

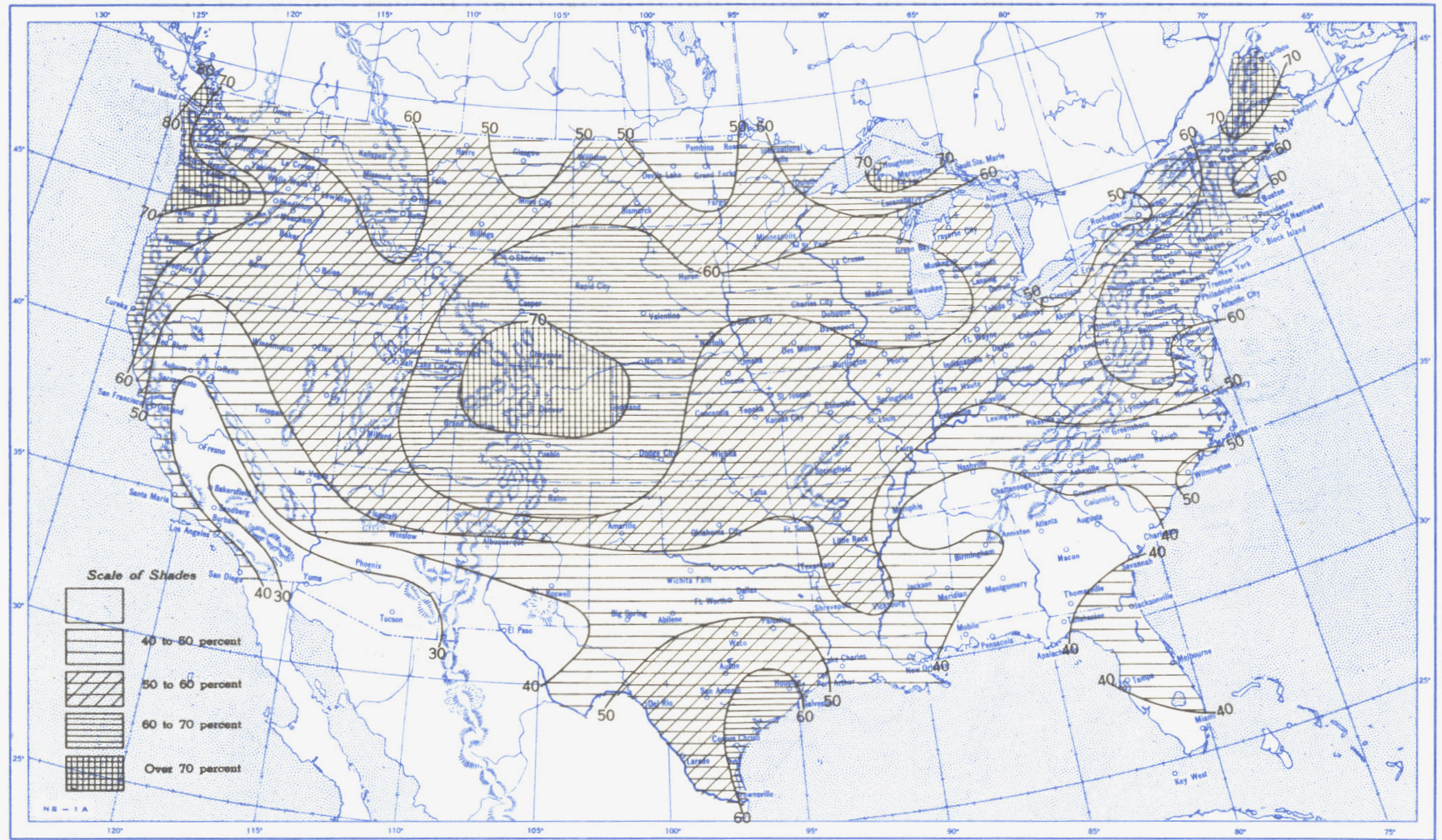

B. Percentage of Normal Sky Cover between Sunrise and Sunset, May 1951.

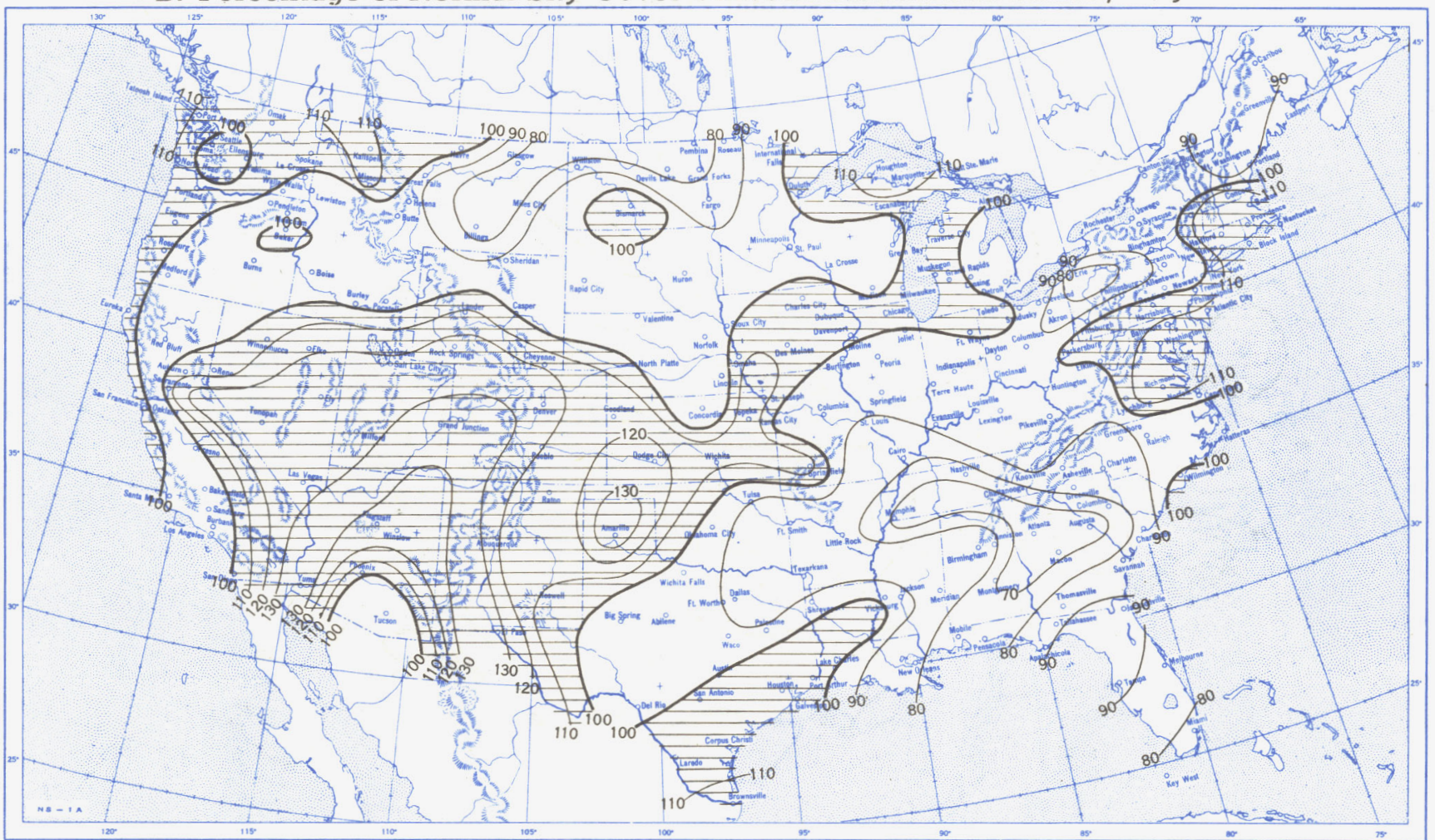

A. In addition to cloudiness, sky cover includes obscuration of the sky by fog, smoke, snow, etc. Chart based on visual observations made hourly at Weather Bureau stations and averaged over the month. B. Computations of normal amount of sky cover are made for stations having at least 10 years of record. 
Chart VII. A. Percentage of Possible Sunshine, May 1951.

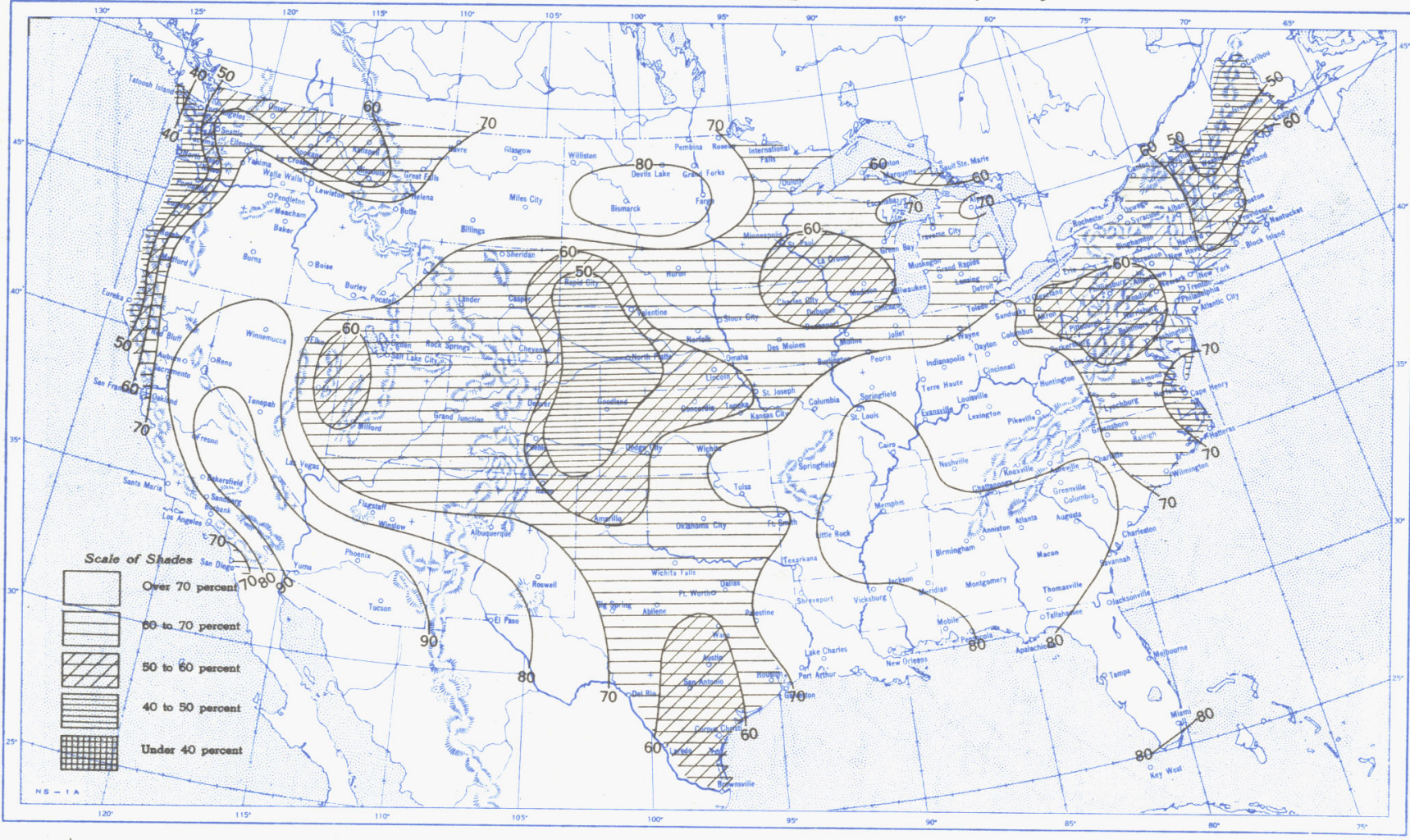

B. Percentage of Normal Sunshine, May 1951.

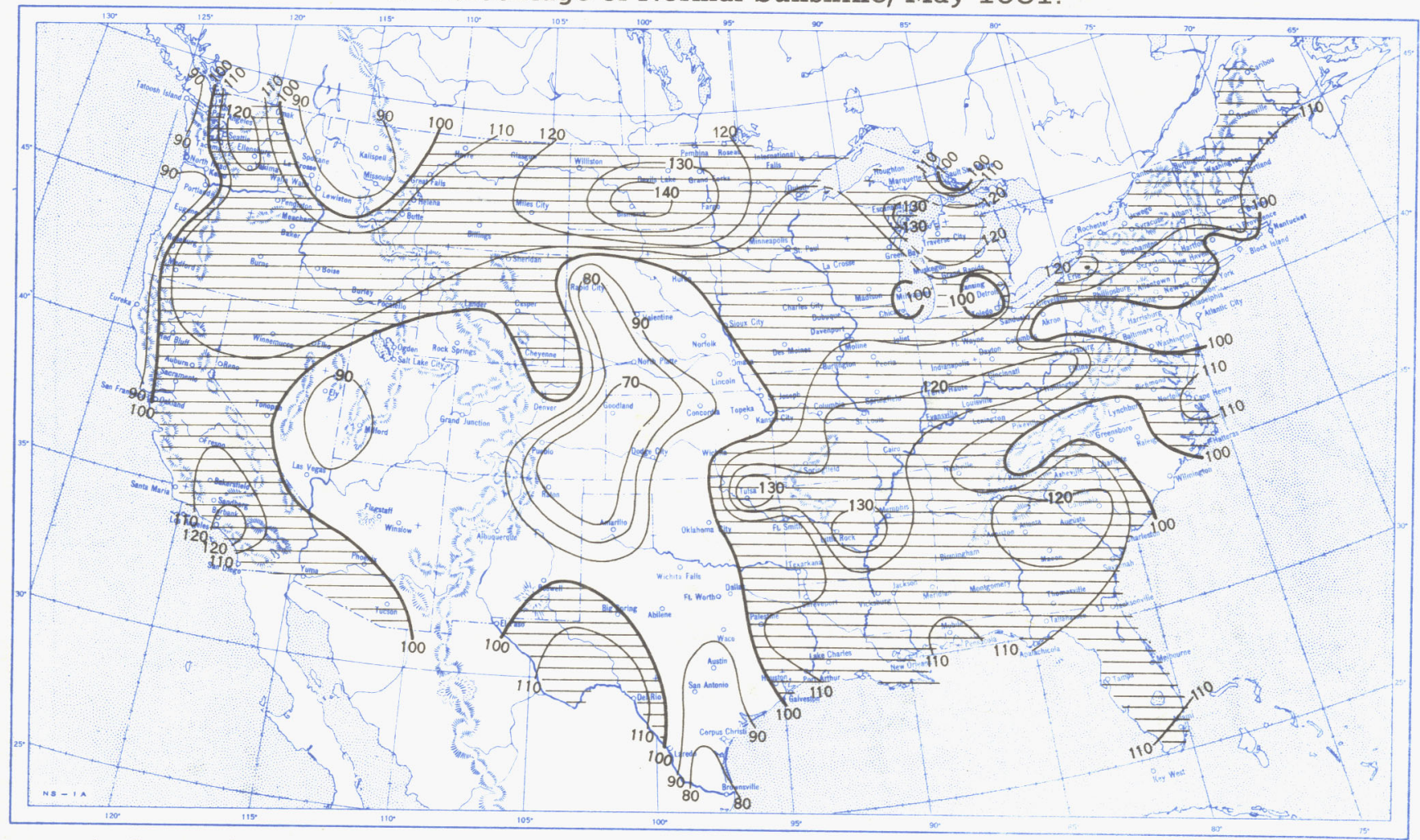

A. Computed from total number of hours of observed sunshine in relation to total number of possible hours of sunshine during month. B. Normals are computed for stations having at least 10 years of record. 


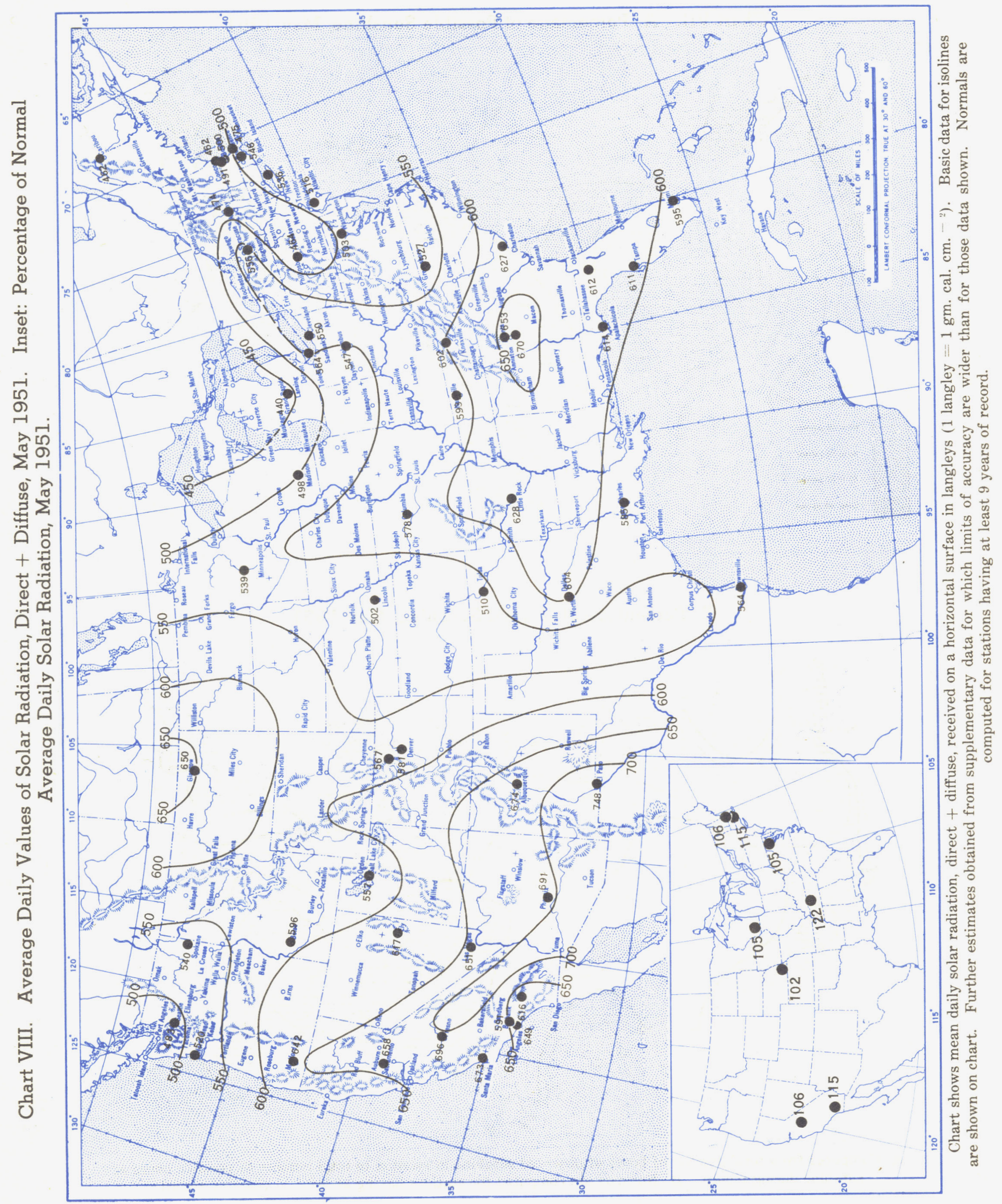




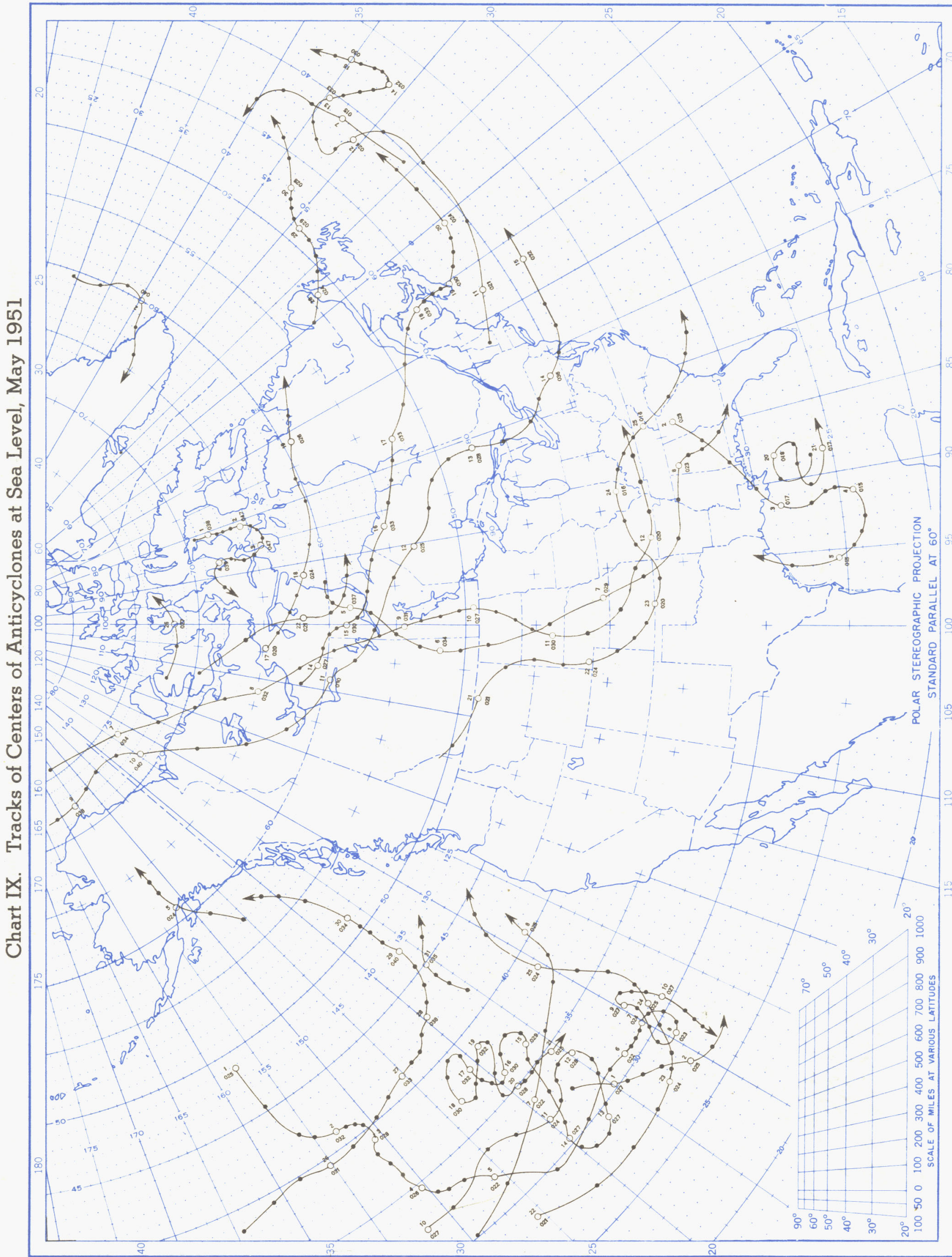

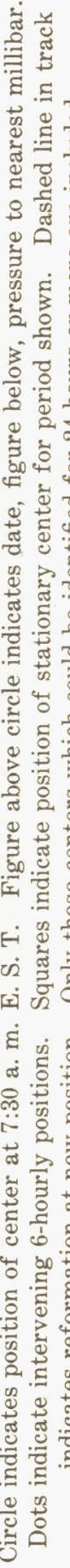




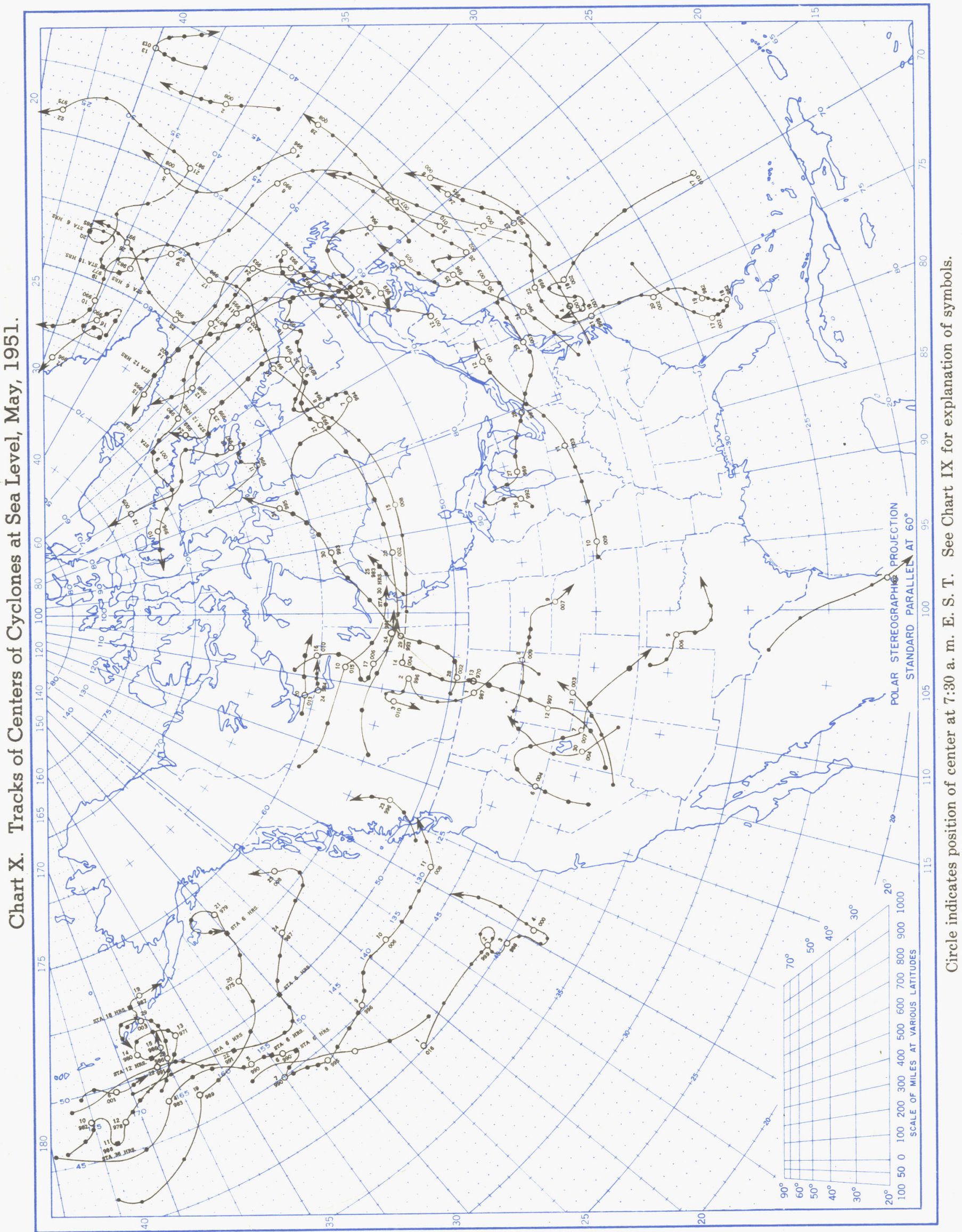




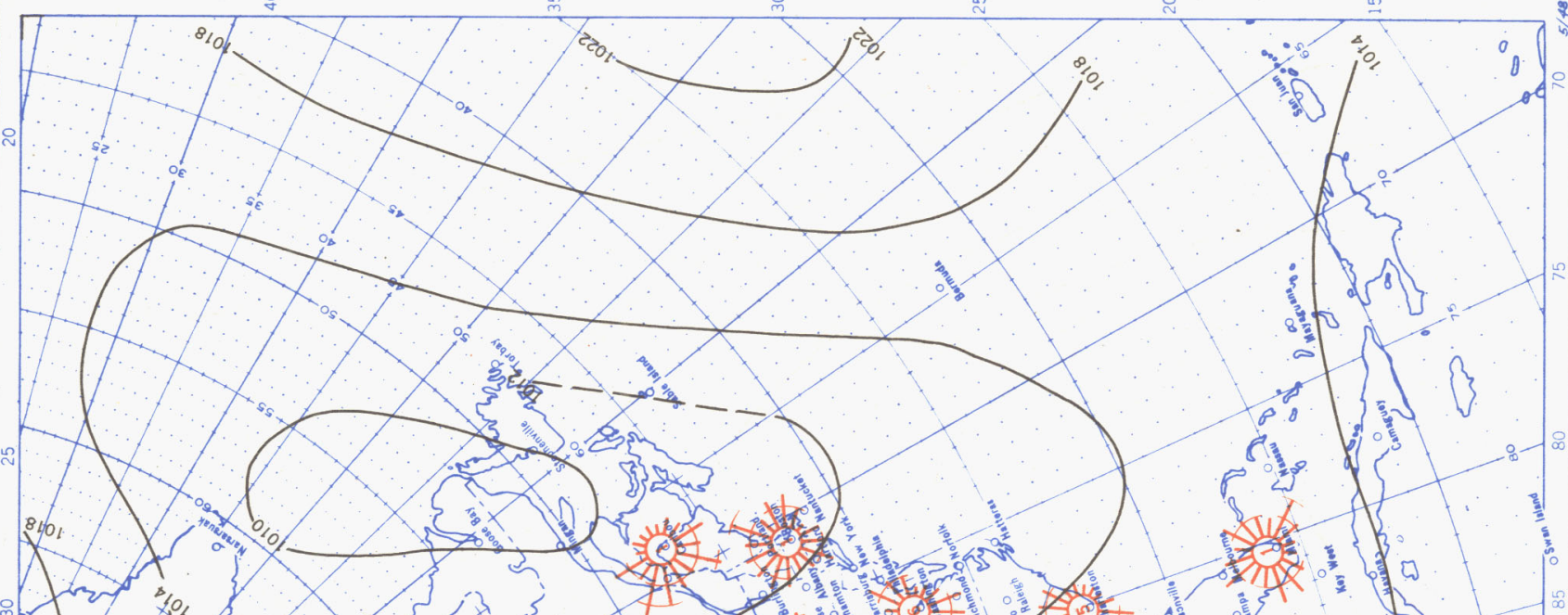

ธี
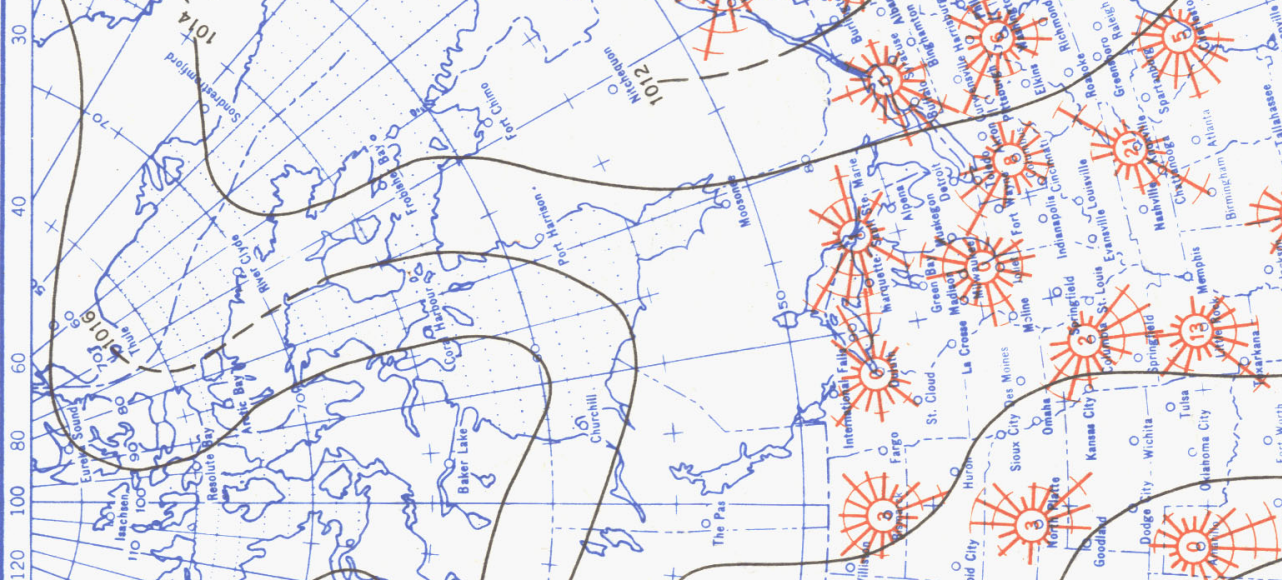

वृ द्वे

ำ

\%
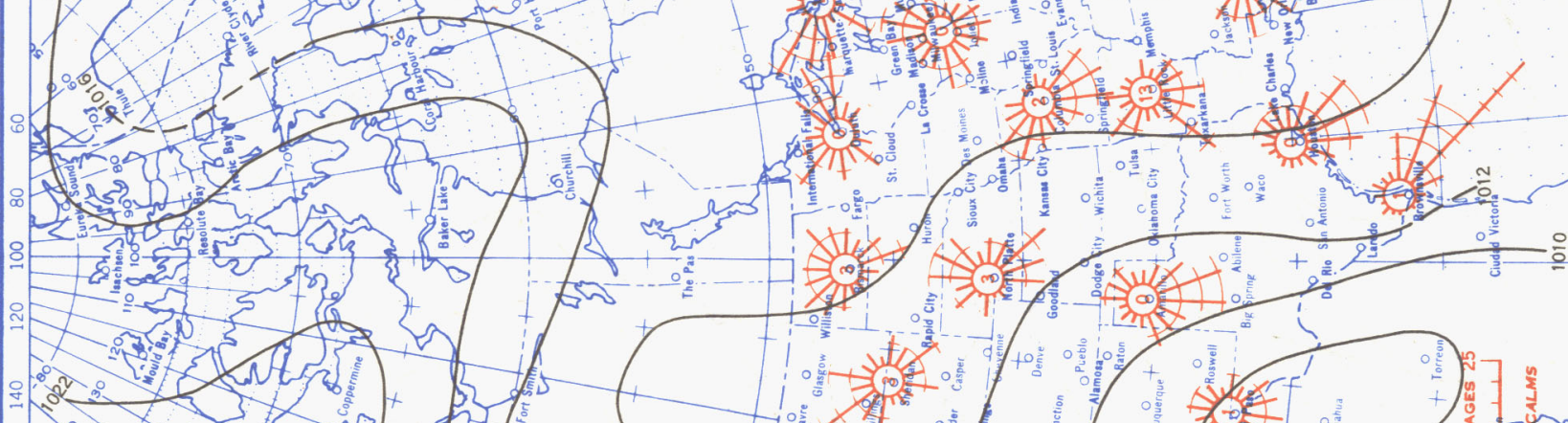

:
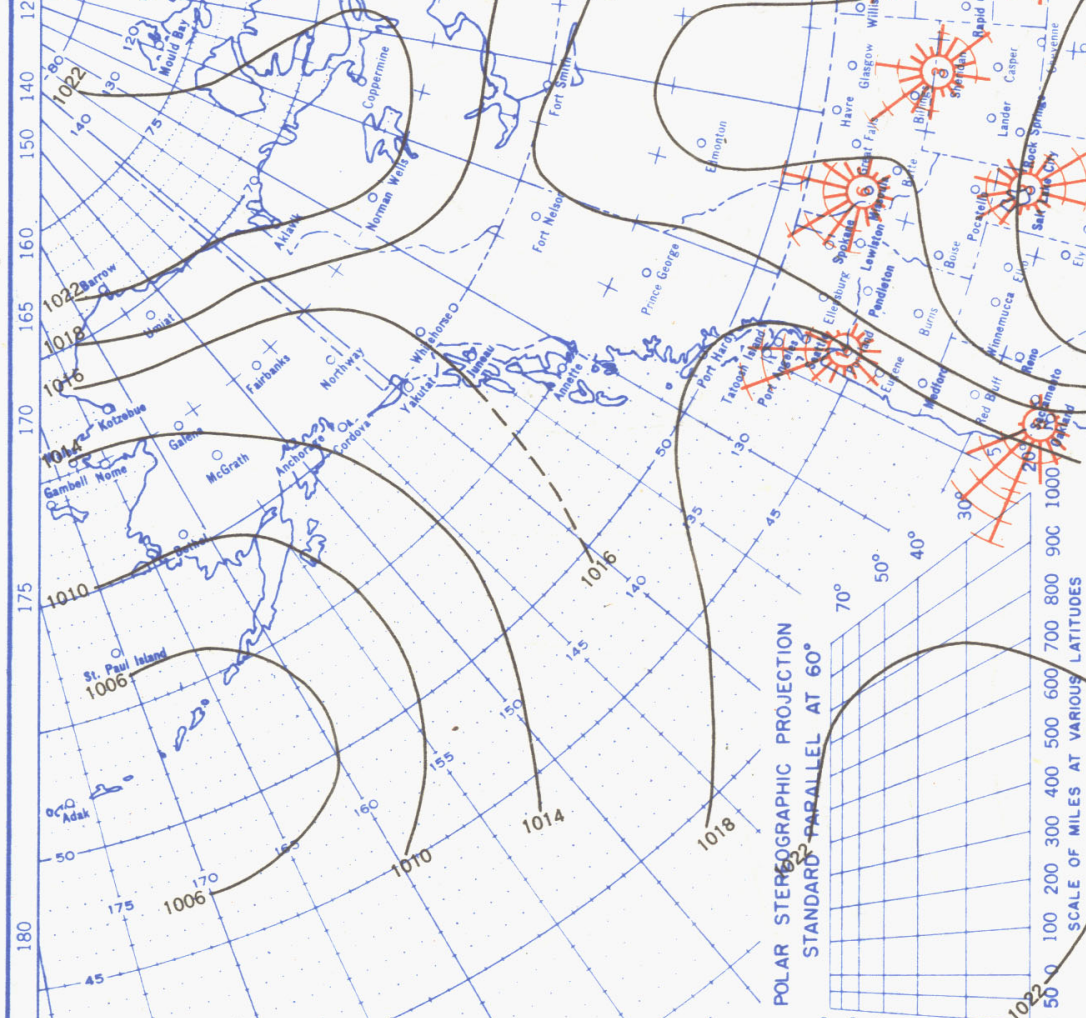

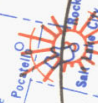
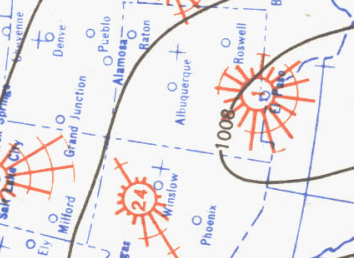

를 웅

है

눙

㻤

政

边

है

क

㣢

要

业及

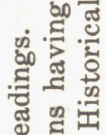

Ð

स

되 원

घं ㅎㅀ

능ㅇ

究 हैं

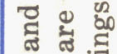

घं ส

๘ है

ชิ 융

ङ 路

पै

on है

串

है है

웡

焉

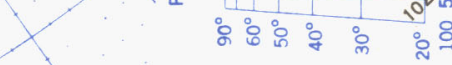

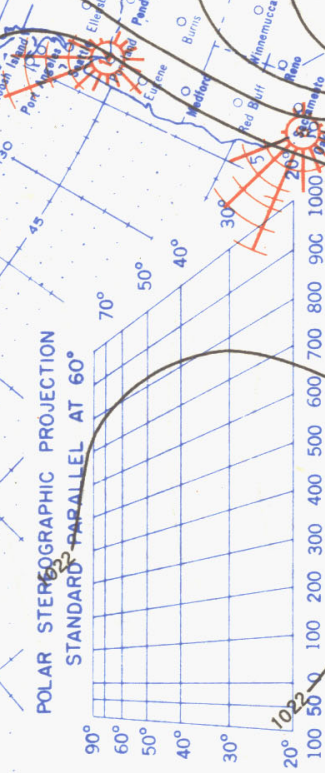

施 


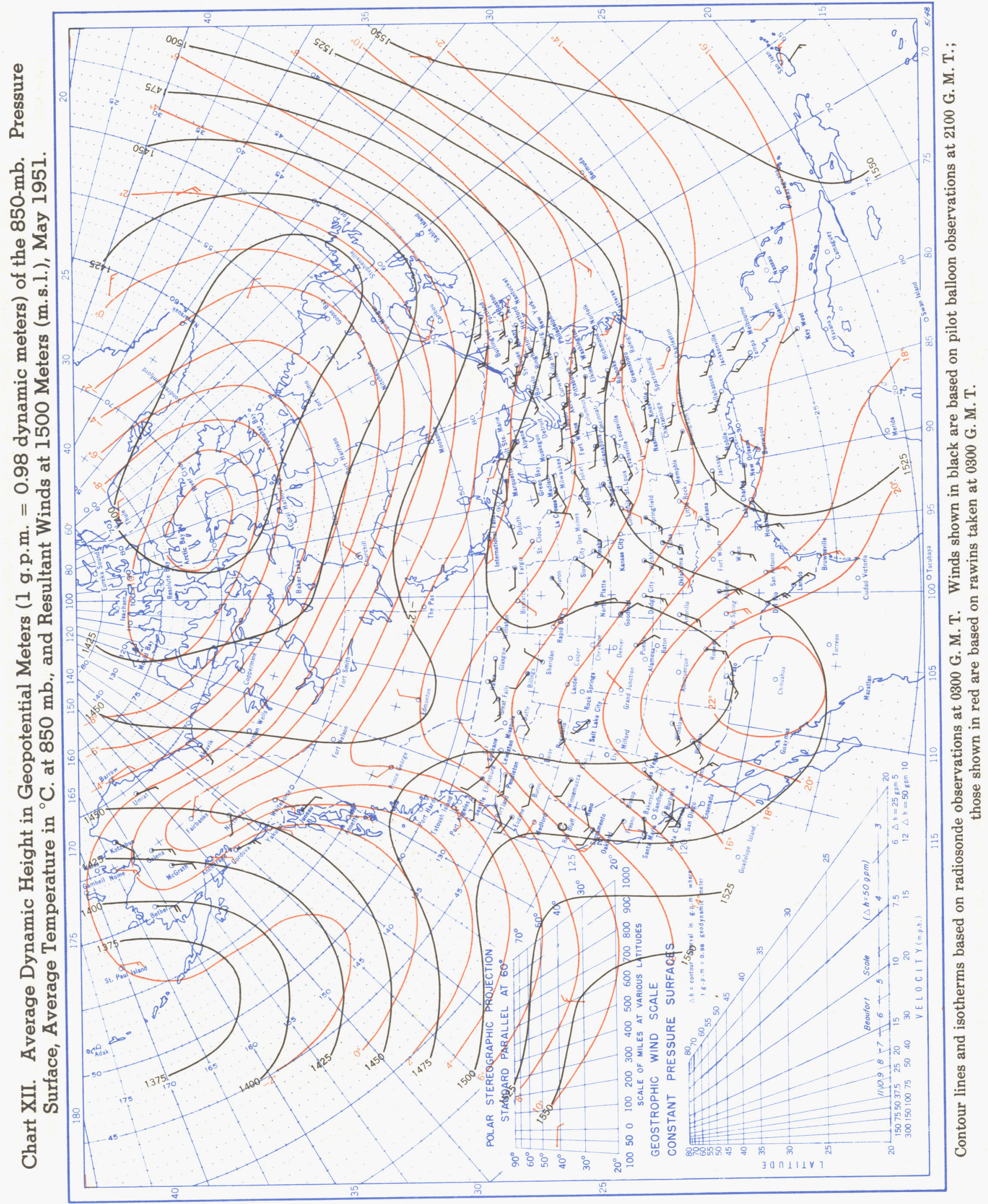


May 1951. M. W. R.

LXXIX-71

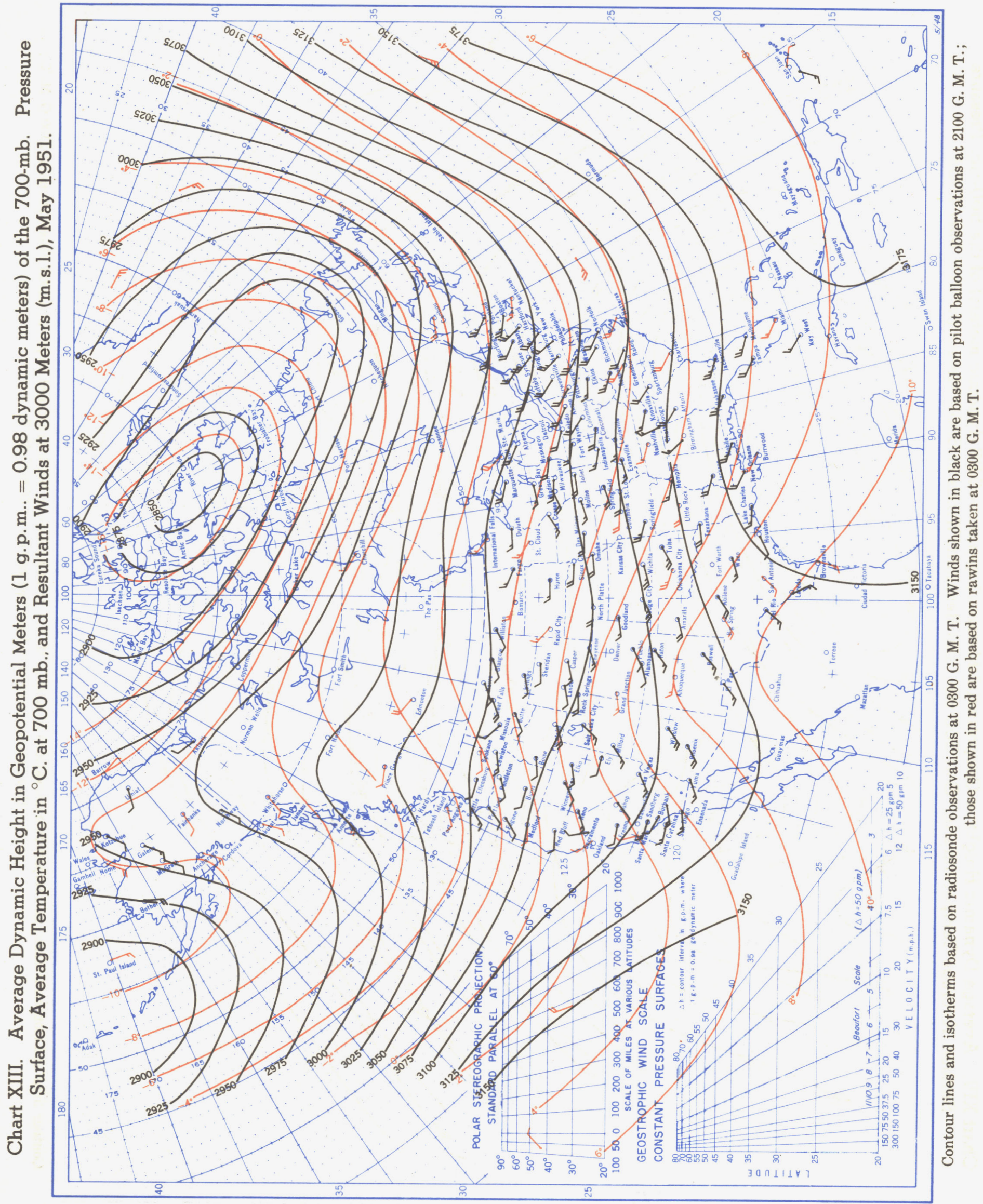




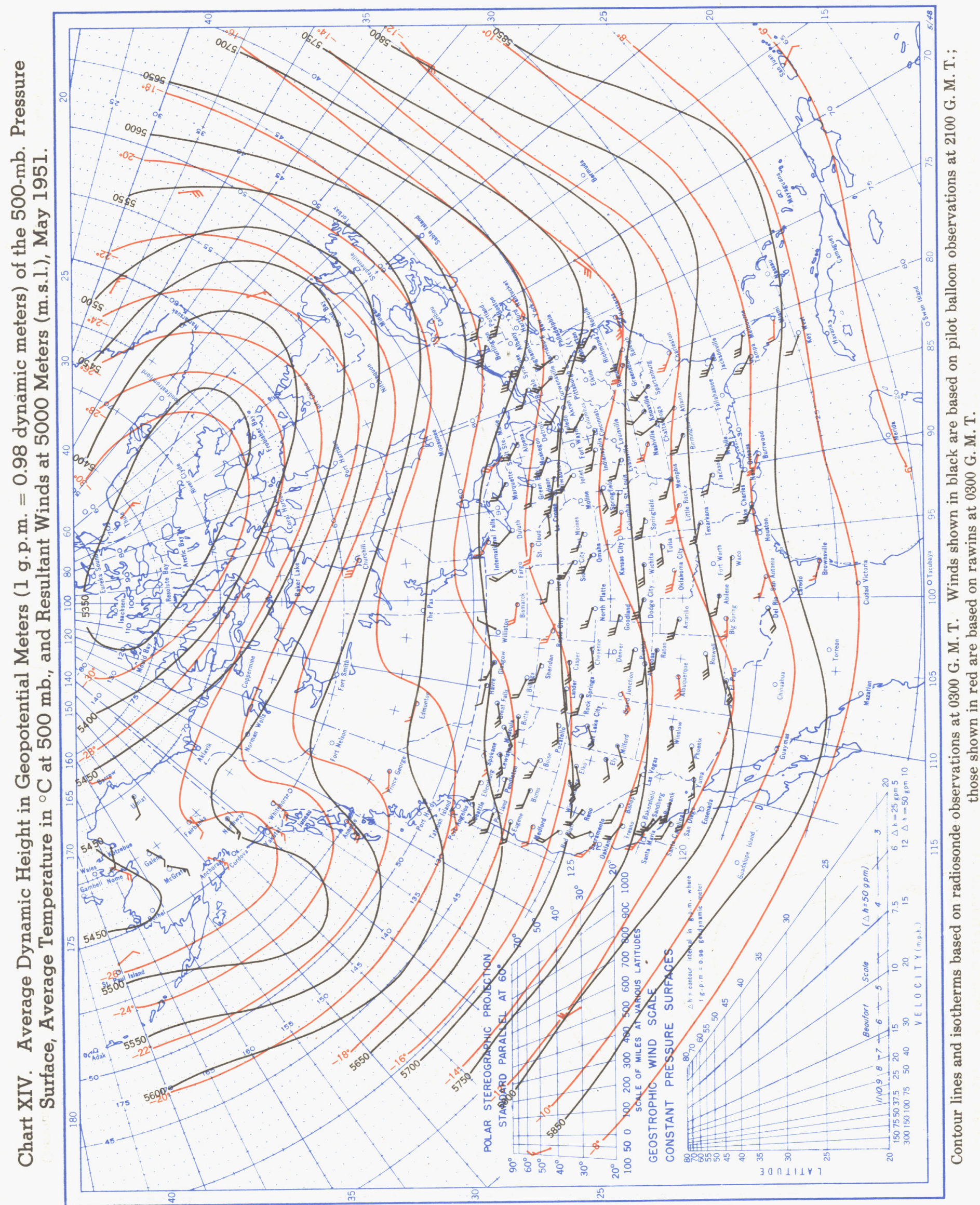


May 1951. M. W. R.

LXXIX -73

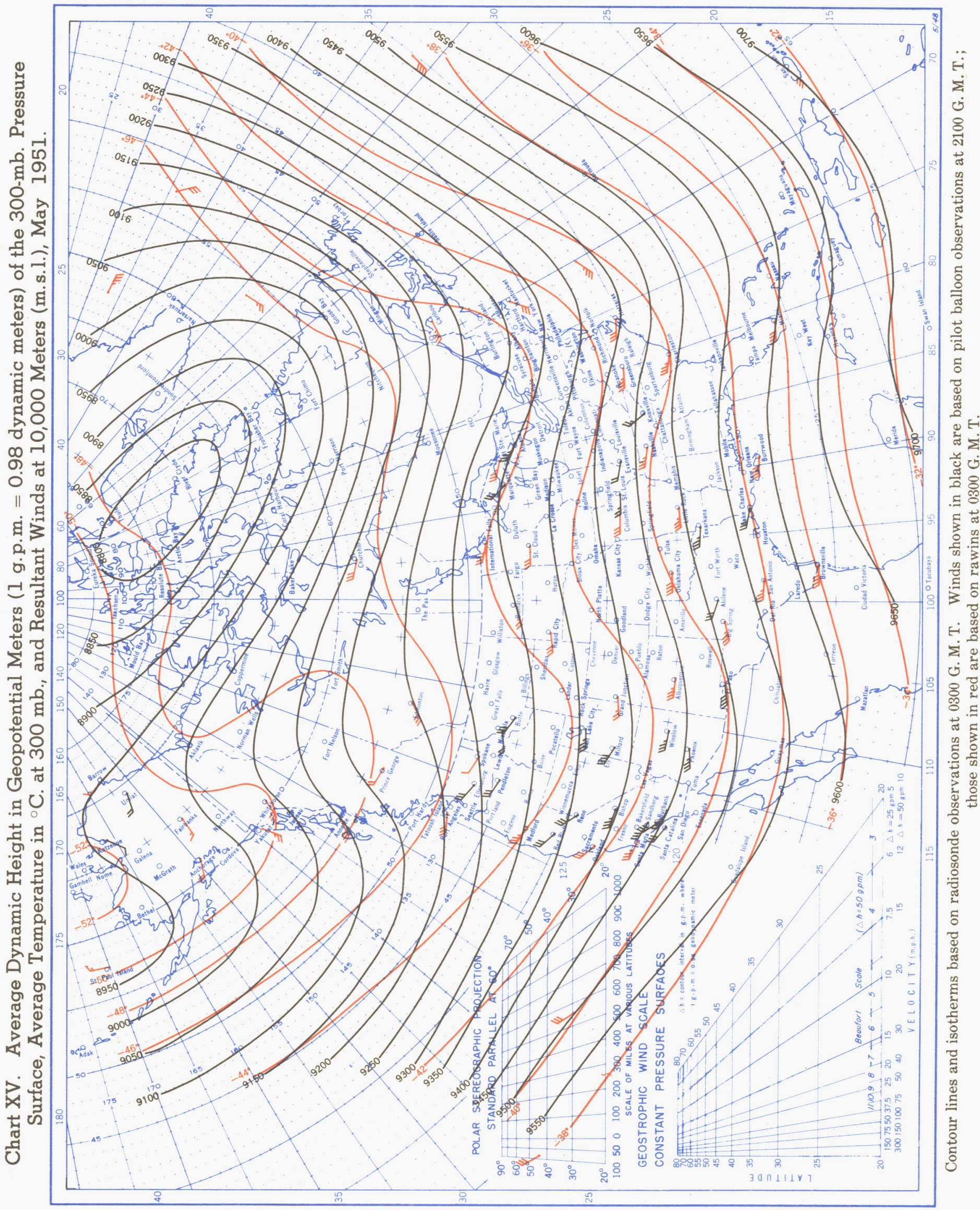

